DOE/FETC-98/1066

\title{
Preparation of CuO/Alumina Absorbents for PETC Flue Gas Sulfur Dioxide Adsorption Process Using Alcoa Alumina Balls CRADA PC93-007, Final Report
}

February 15, 1996

Richard R. Burr

E.S. Martin

RECEIVED

FFR 251998

U.S. Department of Energy

Pittsburgh Energy Technology Center

OSTI

626 Cochrans Mills Road

Pittsburgh, PA 15236

and

Alcoa Technical Center

100 Technical Drive

Alcoa Center, PA 15069-0001

THIS DOCUMENT CONTAINS PROTECTED CRADA INFORMATION, WHICH WAS PRODUCED ON 02/15/96 UNDER CRADA PC93-007, AND IS NOT TO BE FURTHER DISCLOSED FOR A PERIOD OF 5 YEARS FROM THE DATE IT WAS PRODUCED EXCEPT AS EXPRESSLY PROVIDED FOR IN THE CRADA. 


\section{DISCLAIMER}

This report was prepared as an account of work sponsored by an agency of the United States Government. Neither the United States Government nor any agency thereof, nor any of their employees, make any warranty, express or implied, or assumes any legal liability or responsibility for the accuracy, completeness, or usefulness of any information, apparatus, product, or process disclosed, or represents that its use would not infringe privately owned rights. Reference herein to any specific commercial product, process, or service by trade name, trademark, manufacturer, or otherwise does not necessarily constitute or imply its endorsement, recommendation, or favoring by the United States Government or any agency thereof. The views and opinions of authors expressed herein do not necessarily state or reflect those of the United States Government or any agency thereof. 


\section{DISCLAIMER}

Portions of this document may be illegible in electronic image products. Images are produced from the best available original document. 
1996 February 15

Report No. 06-95-13

\section{ALCOA TEGHNICAL GENTER} 100 TECHNICAL DRIVE - ALCOA CENTER, PA 15069-0001

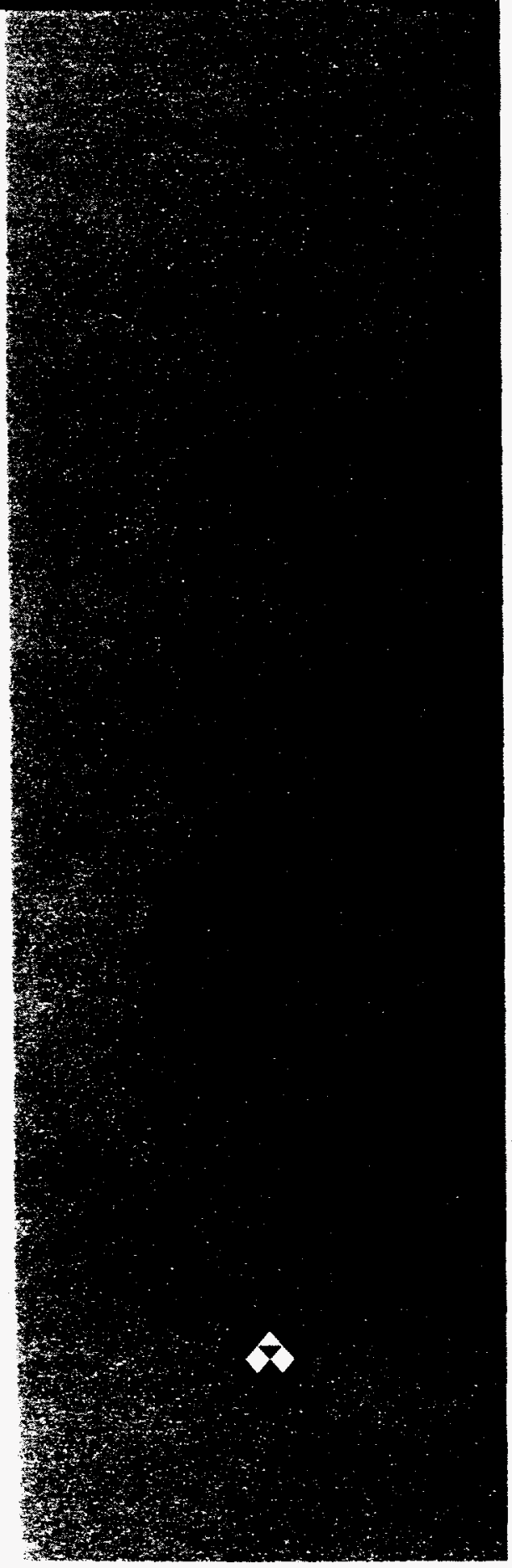

Preparation of $\mathrm{CuO} /$ Alumina Absorbents for Pittsburgh Energy Technology Center [PETC] Flue Gas Sulfur Dioxide Absorption Process Using Alcoa Alumina Balls - Report for PETC Cooperative Research and Development Agreement

Richard R. Burr and E. S. Martin Chemicals and Refining Section

Creating Value through Technology 


\section{ALUMINUM COMPANY OF AMERICA}

\section{ALCOA TECHNICAL CENTER}

\section{PROTECTED CRADA IMFORMATION}

Preparation of CuO/Alumina Absorbents for Pittsburgh Energy Technology Center [PETC] Flue Gas Sulfur Dioxide Absorption Process Using Alcoa Alumina Balls Report for PETC Cooperative Research and Development Agreement

By

Richard R. Burr and Edward S. Martin

Chemicals and Refining Section

1996 February 15

Reported by: $\frac{x \cdot c / i<\text { ad }}{\text { Richard R. Burr, Technologist }}$

Reported by:

E. S. Martin, Scientific Associate 


\section{EXECUTTVE SUMMARY}

This work was done as part of Alcoa - PETC Cooperative Research and Development Agreement No. PC-93007.

Alcoa alumina balls [ $7 \times 14$ mesh] have been loaded with $\mathrm{CuO}$ by using a slight modification of the cupric nitrate impregnation process developed by the U.S. Department of Energy Pittsburgh Energy Technology Center [PETC]. The pre-treated Alcoa Alumina B based material showed satisfactory chemical reactivity in the PETC sulfur dioxide absorption process, but had less attrition resistance than the original oil drop aluminas used by PETC. The $\mathrm{CuO} /$ alumina based on the "Alumina A" (surface stabilized) alumina balls had better attrition resistance, but it had lower reaction rates with $\mathrm{SO}_{2}$ and regeneration rates.

Alumina balls were loaded with cupric sulfate after pretreatment. This allows a simpler absorbent production process [no calcination and no $\mathrm{NO}_{\mathrm{x}}$ emissions] than the cupric nitrate process. The materials prepared on Alcoa Alumina $B$ had better chemical reactivity and less attrition resistance than those prepared on the Alumina A balls, as in the case of the $\mathrm{CuO} /$ alumina materials.

Copper loadings were too low for the PETC process when alumina balls were reacted with ammoniacal cupric sulfate solutions with reasonable solution / alumina ratios. This reaction also generated considerable amounts of fines. 


\section{TABLE OF CONTENTS}

\section{Page}

Executive Summary .................................................................................................... i

List of Tables ................................................................................................................ iii

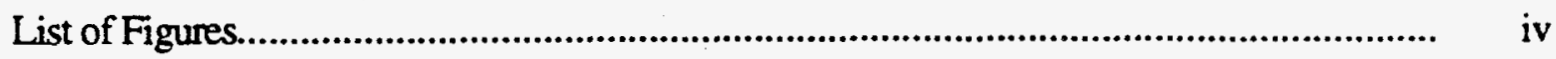

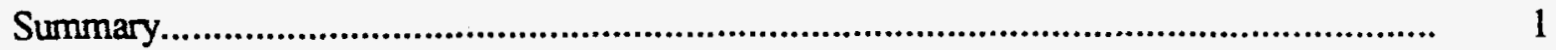

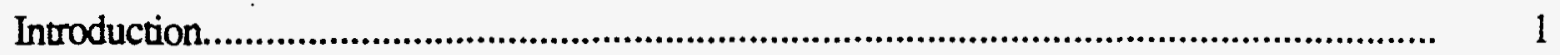

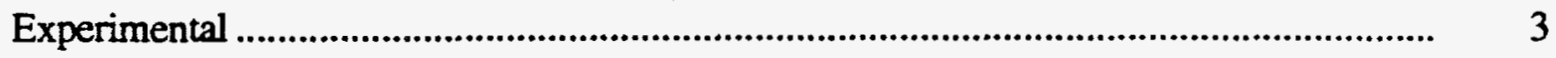

Discussion of Results......................................................................................................

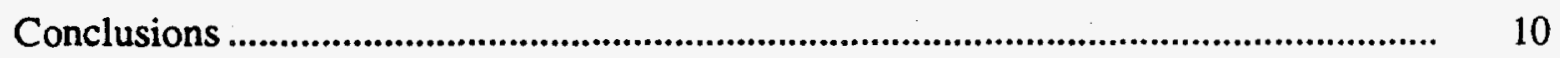

$\mathrm{C} / 0316 \mathrm{P}-\mathrm{ii}-$ 


\section{LIST OF TABLES}

Table 1 Properties of the Original Alumina Balls

Table 2 Effect of Increased Activation Temperature on Ball Strength - 1/8 inch S400

Table 4 Preparation Conditions for Alumina Balls Used in $\mathrm{CuO} / \mathrm{Al}_{2} \mathrm{O}_{3}$ Preparation

Table 5 Cupic Nitrate Loading

Table $6 \% \mathrm{Cu}$ from Pore Volume and Solution Concentration

Table 7 Properties of $\mathrm{CuO} / \mathrm{Al}_{2} \mathrm{O}_{3}$ Samples Supplied to PETC

Table 8 Percent Copper in $\mathrm{CuO} / \mathrm{Al}_{2} \mathrm{O}_{3}$ Analyses by Different Labs and Methods

Table 11 Ammoniacal Copper Sulfate Reaction with Alumina Balls

Table 12 Copper Sulfate Samples

Table 13 Alumina Loaded with Copper Sulfate

Table 14 Samples Prepared at $42^{\circ} \mathrm{C}$

Table 15 Loading Alumina Balls with Cupric Sulfate: Effect of Ball Size 


\section{LIST OF FIGURES}

Figure 1 EDX Dot Map of 25351-17-1

Figure 2 SEM of 25351-17-1

Figure 3 EDX Dot Map of 25351-17-4

Figure 4 SEM of $25351-17-4$

Figure 5 EDX Dot Map of Blue Part of 25351-17-5

Figure 6 EDX Map of 25351-17-5 Including White Area (Left Center)

Figure 7 EDX Map of 25351-17-6

Figure 8 SEM of $25351-17-6$

Figure 9 Comparison of Predicted and Analyzed Copper Levels 


\section{Summary}

Alcoa alumina balls [ 7 x14 mesh] have been loaded with $\mathrm{CuO}$ by using a slight modification of the cupric nitrate impregnation process developed by the U.S. Department of Energy Pittsburgh Energy Technology Center [PETC]. The pretreated Alcoa Alumina B based material showed satisfactory chemical reactivity in the PETC sulfur dioxide absorption process, but had less attrition resistance than the original oil drop aluminas used by PETC. The CuO/alumina based on the "special" (Alcoa Alumina A) alumina balls had better attrition resistance, but it had lower reaction rates with $\mathrm{SO}_{2}$ and regeneration rates. (By "special" alumina balls [Alcoa Alumina $\mathrm{A}$ ], we mean alumina balls made with proprietary additive which strengthens the balls and improves their resistance to sintering.)

Alumina balls were loaded with cupric sulfate after neutralization. This allows a simpler absorbent production process [no calcination and no $\mathrm{NO}_{\mathrm{x}}$ emissions] than the cupric nitrate process. The materials prepared on Alcoa Alumina $B$ had better chemical reactivity and less attrition resistance than those prepared on Alcoa Alumina A balls, as in the case of the $\mathrm{CuO}$ / alumina materials.

Copper loadings were too low for the PETC process when alumina balls were reacted with ammoniacal cupric sulfate solutions with reasonable solution/alumina ratios. This reaction also generated considerable amounts of fines.

\section{Introduction}

This work was done as the Alcoa part of a Cooperative Besearch and Development Agreement ["CRADA"] between Alcoa and the Bittsburgh Energy Technology Center [PETC] of the United States Department of Energy. A copy of the statement of work for this agreement is attached to this report as Appendix I.

The first task in this project was to prepare copper oxide loaded alumina balls from Alcoa alumina balls using the procedure developed by PETC. The alumina balls were to be $1.5 \mathrm{~mm}$ average diameter $[=7 \times 14$ mesh $=1 / 16$ inch], so that the material could be fluidized.

The CuO/alumina balls are to be used in the PETC flue gas $\mathrm{SO}_{2}$ removal and nitrogen oxide decomposition process. The chemistry of the $\mathrm{SO}_{2}$ removal and nitrogen oxide decomposition is given in the following equations: 1 
Sulfur Dioxide Removal

$$
\begin{gathered}
\mathrm{CuO}(\mathrm{s})+\mathrm{SO}_{2}(\mathrm{~g})+0.5 \mathrm{O}_{2}(\mathrm{~g}) \cdots-\cdots \mathrm{CuSO}_{4}(\mathrm{~s}) \\
400-480^{\circ} \mathrm{C}
\end{gathered}
$$

\section{CuO Regeneration}

$$
\mathrm{CuSO}_{4}(\mathrm{~s})+0.5 \mathrm{CH}_{4}(\mathrm{~g})-\cdots-\mathrm{Cu}(\mathrm{s})+\mathrm{SO}_{2}(\mathrm{~g})+0.5 \mathrm{CO}_{2}(\mathrm{~g})+\mathrm{H}_{2} \mathrm{O}(\mathrm{g})
$$

The reduction of the copper sulfate can also be done with hydrogen, carbon monoxide, or mixtures of the two ["synthesis gas"] under similar conditions. The copper is oxidized to cupric oxide by the residual oxygen in the flue gas when the balls are returned to the absorber.

$$
\mathrm{Cu}+0.5 \mathrm{O}_{2}(\mathrm{~g}) \cdots-\cdots \mathrm{CuO}(\mathrm{s})
$$

The alumina is the carrier for the copper compounds. It allows the copper compounds to be sufficiently dispersed for the sulfur dioxide to react with most of the $\mathrm{CuO}$ and the product copper sulfate to be reduced at a practical rate. Pure copper oxide would not react completely either in the absorption or the regeneration step, due to mass transfer limitations. This is illustrated by the surface area of pure $\mathrm{CuO}$ [Fisher C474-500], which was too low to be measured by the nitrogen BET method [<0.2 $\mathrm{m}^{2} / \mathrm{g}$; ATC ANCH J.0. 94-070510].

\section{Nitrogen Oxides Removal [Catalyzed by $\mathrm{CuSO}_{4}$ and/or CuO]:}

The nitrogen oxides are reduced by ammonia in the reactor in which the sulfur dioxide is being absorbed. Both $\mathrm{CuO}$ and $\mathrm{CuSO}_{4}$ are catalysts for the reaction of ammonia with nitrogen oxides to form elemental nitrogen. 1

$$
\begin{aligned}
& 6 \mathrm{NO}(\mathrm{g})+4 \mathrm{NH}_{3}(\mathrm{~g}) \ldots \ldots>5 \mathrm{~N}_{2}(\mathrm{~g})+6 \mathrm{H}_{2} \mathrm{O}(\mathrm{g}) \\
& 6 \mathrm{NO}_{2}(\mathrm{~g})+8 \mathrm{NH}_{3}(\mathrm{~g}) \ldots \ldots>7 \mathrm{~N}_{2}(\mathrm{~g})+12 \mathrm{H}_{2} \mathrm{O}(\mathrm{g})
\end{aligned}
$$




\section{Experimental}

The alumina balls were all samples of commercial production from Alcoa's Vidalia, LA, works. The cupric nitrate [Fisher C467-500] and cupric sulfate [Fisher 493-500] were both reagent grade.

\section{Loading by the PETC Cupric Nitrate Method}

The drying and calcination of the cupric nitrate solution loaded balls followed the procedure $[1$, p. 223] described by PETC as closely as possible. The only exception was that the calcination of the cupric nitrate loaded balls was done in air instead of nitrogen. The procedure is outlined below.

1. Soak the neutralized and dried $\mathrm{Al}_{2} \mathrm{O}_{3}$ balls in aqueous $\mathrm{Cu}\left(\mathrm{NO}_{3}\right)_{2}$. The soaking time was selected by breaking a sample of 4 or 5 balls at various times. When each fractured ball appeared blue to the center [to the unaided eye], the soak time was considered to be sufficient.

2. Dry at $150^{\circ} \mathrm{C}$ for 16 hours.

3. Calcine at $650^{\circ} \mathrm{C}$ for 6 hours. The result is the decomposition of the copper nitrate according to the equation given below. This was done at $650^{\circ} \mathrm{C}$ for the materials prepared for PETC because this was the recipe used in the original PETC work. Some later materials were calcined at $450^{\circ} \mathrm{C}$ or at $550^{\circ} \mathrm{C}$, because other work ${ }^{2}$ has shown that cupric nitrate is completely decomposed to $\mathrm{CuO}$, even at $400^{\circ} \mathrm{C}$. The lower calcination temperature retains more of the strength of the alumina balls. ${ }^{3}$

$$
\mathrm{Cu}\left(\mathrm{NO}_{3}\right)_{2}(\mathrm{~s})-\ldots--->\mathrm{CuO}(\mathrm{s})+2 \mathrm{NO}_{2}(\mathrm{~g})+\mathrm{O} .5 \mathrm{O}_{2}(\mathrm{~g})
$$

\section{Ammoniacal Copoer Sulfate Method}

Several batches of alumina balls were treated using the method developed by J. A. Lowe and W. H. Quayle in 1991.4 This method uses a solution which is $0.25 \mathrm{M}$ in $\mathrm{CuSO}_{4}$ and $1.0 \mathrm{M}$ in ammonia, and the reaction is carried out at room temperature or $50^{\circ} \mathrm{C}$. The product is a mixed copper aluminum sulfate hydroxide, which has not been previously identified [i.e., its X-ray 
diffraction pattern does not match any pattern in the JCPDS database]. This compound decomposes to $\mathrm{CuO}$ and alumina on heating to $600-700^{\circ} \mathrm{C} .^{4}$

\section{Loading Alumina Balls with Copper Sulfate}

The alumina balls were pretreated. The balls were then washed with deionized water and dried at $250^{\circ} \mathrm{C}$ under vacuum. The cupric sulfate solution concentration was selected to give the desired copper loading, assuming that the complete pore volume of the alumina balls would be filled with the cupric sulfate solution and that all of the copper sulfate would remain when the balls were dried. The dried balls were then soaked until a sample of four or five balls appeared blue to the center when broken. The remaining copper sulfate solution was drained off and the impregnated balls were dried at $100^{\circ} \mathrm{C}$ under a water aspirated vacuum. The samples submitted to PETC for physical and chemical testing were heated to $510^{\circ} \mathrm{C}$ (at PETC's request) to match the highest regeneration temperature which the absorbent may see.

\section{Discussion of Results}

\section{A. Materials Prepared by the PETC Process}

Initial tests were done with 1/8' Alcoa Alumina D and three concentrations of copper nitrate solution to establish a connection between solution concentration and the final copper oxide loading in the finished balls. Untreated balls and balls pretreated in two ways were used as the base materials. The pretreated balls had higher final levels of copper than the as received balls [compare 25351-17-1 and 25351-17-2 with 25351-17-3 through 25351-17-6]. Pretreated balls were used for all subsequent tests, because this result fit with the predicted tendency of copper salts to hydrolyze [to precipitate $\mathrm{Cu}(\mathrm{OH})_{2}$ ] at $\mathrm{pH}$ levels between 9 and 11 [5, pp. 273-274].

The uniformity of the distribution of copper in the CuO/alumina balls produced in the first two series was examined by Energy Dispersive X-ray [EDX] analysis of cross sections of cut balls. The dot maps showed uniform copper distribution, except for one case in which there were white spots in the pellet examined [25351-17 series, see Table 5 and Figures 1-8]. This suggests at least qualitative uniformity of the copper distribution across three of the four pellets for which EDX maps could be obtained. Pellets from samples 25351-35-2, -35-3, and 25351-46-1 were examined by XPS [ESCA] at PETC. They found considerably higher $\mathrm{Cu} / \mathrm{Al}$ ratios on the outside of 25351-35-2 and 25351-46-1 than in the center of these pellets [Reference 7, Table 4]. This is surprising, since these last were $1.5 \mathrm{~mm}$ pellets. and the 
alumina balls examined at ATC by EDX were all $3 \mathrm{~mm}$ in diameter. Some difference between these results may be due to the larger sampling depth of EDS [a few micrometers] than XPS [ESCA] which is 7.5 nanometers. One would expect that the larger balls would be more likely to have non-uniform distributions of copper than the smaller diameter balls. (Note: EDX was not obtained on samples 25351-17-2 and 25351-17-3 because of sample charging.)

The results of the impregnation of alumina balls by cupric nitrate are shown in Table 5 . The earliest tests [25351-17 and 25351-18] were done to provide an empirical test of the connection between the cupric nitrate solution volume and the concentration of copper in the final product. The rest of the test materials were prepared by calculating the amount of $\mathrm{CuO}$ which could be produced by decomposing the copper nitrate found the volume of solution which would fit in the pore volume of the batch of alumina balls being used (see Appendix II for details).

PETC wished to have the copper level in the $\mathrm{CuO} / \mathrm{Al}_{2} \mathrm{O}_{3}$ materials between 6.5 and $7.5 \mathrm{wt} . \%$ $\mathrm{Cu}$. The range is set by the need to have as much $\mathrm{CuO}$ as possible in the sorbent, but limited by the tendency of the sorbent to decrepitate if the copper level is above $7.5 \mathrm{wt} . \%$ [as $\mathrm{Cu}$ ]. ${ }^{6 \mathrm{a}}$ Other work ${ }^{2,6 \mathrm{~b}}$ suggests that well dispersed copper is most reactive, and that copper levels above the level which permits good dispersion will not increase $\mathrm{SO}_{2}$ absorption.

The comparison between the calculated and measured $\mathrm{Cu}$ levels is shown in Table 5 and Figure 9. The method of calculation of the copper levels from the ball pore volume and copper salt solution concentration is shown in Appendix II. The results show that the predictions of the copper level from the alumina pore volume and the cupric nitrate solution volume is inaccurate. The standard deviation of the difference between the predicted and measured copper values is $17.1 \%$ of the mean of the measured and calculated copper levels. This variability occurred even when identical base alumina balls and identical cupric nitrate solutions were used. Compare 25817-37 and 25817-37-1 with 25817-49-2 where identical starting materials were used in each case, and yet the copper levels ranged from 9.8 to $6.8 \%$. For $25817-42$ and 25817-42-1 the copper levels were above $11 \%$, but only $8.3 \%$ for $25817-49-1$; again, aliquots of the same batch of alumina balls and the same $\mathrm{Cu}\left(\mathrm{NO}_{3}\right)_{2}$ solution concentrations were used in all three tests.

The $\mathrm{CuO} / \mathrm{Al}_{2} \mathrm{O}_{3}$ samples calcined at 450 and $550^{\circ} \mathrm{C}$ have surface areas above $240 \mathrm{~m}^{2} / \mathrm{g}$ [Table 13]; the materials calcined at $650^{\circ} \mathrm{C}$ have surface areas below $200 \mathrm{~m}^{2} / \mathrm{g}$ [Table 5]. This is what one would expect from the effect of calcination temperature on alumina surface area. ${ }^{3}$ 
Note on the Analysis of $\mathrm{CuO} / \mathrm{Al}_{2} \mathrm{O}_{3}$ Balls for Copper Content

Five batches of $\mathrm{CuO} / \mathrm{Al}_{2} \mathrm{O}_{3}$ balls were analyzed by outside laboratories as well as by Alcoa Technical Center's Analytical Chemistry Division. In three of these cases, there was substantial disagreement between the ATC and the outside analyses. The results are shown in Tables 8 and 9 [Tables 1 and 2 from Reference 7]. The cause of the disagreement in copper percentage may be due either to non-uniform samples or to differences in the analytical procedures. The main procedural difference between laboratories was the method used to dissolve the $\mathrm{CuO} / \mathrm{Al}_{2} \mathrm{O}_{3}$ prior to either atomic absorption or inductively coupled plasma analysis. Alcoa Technical Center's Analytical Chemistry Division uses a lithium tetraborate fusion procedure to dissolve each sample, while PETC uses hydrochloric acid with hydrogen peroxide, and PETC's contract laboratory uses a nitric/perchloric acid digestion.

The possibility of non-uniform samples was suggested by the observation of white flakes in one ground sample. This lead to specification of finer grinding [ -325 mesh vs. the original -100 mesh] for subsequent analyses. The finer grinding appeared to give a much more uniform powder. It is necessary to start with larger samples when larger balls are analyzed in order to obtain representative samples. Sample size problems cannot easily account for the disagreements between laboratories, since the tests were all done on the smallest size of balls [ $7 \times 14$ mesh, $2.83 / 1.19 \mathrm{~mm}$ ], for which more than 100 balls are needed to make one gram. The sample would still be unrepresentative if the balls in the sample were not selected randomly [e.g., the sampling method selected either the most or least dense balls in the sample].

\section{Performance of the CuO/Alumina Materials in the PETC Process}

The materials prepared in this project have been tested on the bench scale by PETC. ${ }^{7}$ The materials based on Alcoa Alumina B and Alcoa Alumina C had good chemical reactivity, but the materials based on the "special" [Alcoa Alumina A] balls lost reactivity after only a few absorption/regeneration cycles. The Alcoa Alumina $C$ balls failed rapidly in the PETC fluidizing attrition test. The Alcoa Alumina B balls held up better than LD5 balls in the attrition test, but were not as good as the original alumina support used by PETC. The Alcoa Alumina A balls had the best attrition resistance of the Alcoa products, but were not as good as the alumina balls which PETC had previously used to make $\mathrm{CuO} / \mathrm{Al}_{2} \mathrm{O}_{3}$ sorbents. 


\section{B. Materials Prepared by the Quayle/Lowe Process}

This method was tested because it offered a good prospect of distributing the copper oxide evenly over the alumina surface.

Quayle and Lowe demonstrated ${ }^{4}$ the reaction of copper amine sulfate solutions with spray dried rehydratable alumina powder which was rehydrated to the extent of having a $25 \%$ LOI. Thus, tests were needed to determine how much copper would be deposited on activated alumina balls. The chemistry of this process [as far as it is understood] is outlined below.

1. Form aqueous copper amine sulfate solution

$$
0.25 \mathrm{M} \mathrm{CuSO}_{4}, 1.0 \mathrm{M} \mathrm{NH}_{3}-->\mathrm{Cu}\left(\mathrm{NH}_{3}\right)_{4} \mathrm{SO}_{4}
$$

2. React with transition alumina balls:

$$
\begin{gathered}
\mathrm{Al}_{2} \mathrm{O}_{3}+\mathrm{Cu}\left(\mathrm{NH}_{3}\right)_{4} \mathrm{SO}_{4} \underset{\mathrm{CuO} / \mathrm{Al} \text { layered compound }}{20-50^{\circ} \mathrm{C}} \\
+ \text { basic aluminum sulfate (?) }
\end{gathered}
$$

The copper levels of the $\mathrm{CuO} /$ alumina materials made by this process were too low unless very large solution volumes were used per weight of alumina balls [Table 11]. The ammoniacal cupric sulfate solutions also developed large amounts of light colored sludge. This suggested the possibility of considerable by-product waste disposal problems if this process were operated on a large scale. For these reasons, work on this approach was stopped.

\section{Alumina Balls Loaded with $\mathrm{CuSO}_{4}$}

The $\mathrm{CuO} / \mathrm{Al}_{2} \mathrm{O}_{3}$ absorbent can be prepared indirectly by impregnating the alumina balls with $\mathrm{CuSO}_{4}$ solution. This idea was proposed at the 1994-07-20 PETC conference in Pittsburgh. Copper sulfate loaded alumina would be added to the regeneration step of the $\mathrm{SO}_{2}$ absorption process. The regeneration process would convert to copper sulfate to $\mathrm{CuO}$, just as it converts the $\mathrm{CuSO}_{4}$ formed in the absorption step by the reaction of $\mathrm{SO}_{2}, \mathrm{CuO}$ and oxygen. The regenerated material is then fed to the absorption step. Copper sulfate is much cheaper than copper nitrate [per unit weight of $\mathrm{CuO}$ produced, ${ }^{8}$ so this method offers the prospect of reduced materials costs. Calcination with the emission of acidic oxides $\left[\mathrm{SO}_{\mathbf{x}}\right.$ or $\left.\mathrm{NO}_{\mathbf{x}}\right]$ is eliminated. 
because the cupric sulfate/alumina balls only need to be dried to remove the solution water [the last water of hydration remains with each mole of $\left.\mathrm{CuSO}_{4}\right]$. Copper sulfate does not thermally decompose until about $650^{\circ} \mathrm{C}, 13$ and the drying temperature will be kept well below this temperature. This would be a considerable help for absorbent production plants which do not have kilns with off gas scrubbers.

Cupric sulfate loading also should avoid decrepitation of the product due to expansion when $\mathrm{CuO}$ is converted to $\mathrm{CuSO}_{4}$, since the copper is deposited in the pores of the alumina as a $\mathrm{CuSO}_{4}$ hydrate in the first place. This should avoid the pressure on the alumina pores caused by the expansion when copper oxide is converted to cupric sulfate [the presumed cause of decrepitation of $\mathrm{Cu} / \mathrm{Al}_{2} \mathrm{O}_{3}$ which contains more than $7.5 \% \mathrm{CuO}{ }^{6}$ ]. This is a hypothesis which must be tested by passing material through several cycles of the PETC $\mathrm{SO}_{2}$ absorption process.

The $\mathrm{CuSO}_{4}$ concentration in the impregnation solution must be sufficient to give the desired copper loading when the pores of the alumina balls are filled with the solution. The water solubility of $\mathrm{CuSO}_{4}$ is too low at roorn temperature to give the desired copper loading with balls which have 0.50 to $0.58 \mathrm{cc} / \mathrm{g}$ pore volume. The desired concentration of $\mathrm{CuSO}_{4}$ [equivalent to $7.5 \mathrm{wt} . \% \mathrm{Cu}$, when the copper is present as $\mathrm{CuO}$ ] can be obtained by heating the solution to about $60^{\circ} \mathrm{C} .{ }^{9}$ The concentration of $\mathrm{CuSO}_{4}$ can be increased by using even higher solution temperatures, but we expect that the solution may attack the alumina balls if the temperature and $\mathrm{CuSO}_{4}$ concentration are increased sufficiently, because cupric sulfate solutions are acidic. and sulfuric acid is known to attack aluminum hydroxide more rapidly than nitric acid. ${ }^{10} \mathrm{By}$ analogy, we expect that other acidic sulfate solutions, such as cupric sulfate, will attack alumina more rapidly than copper nitrate solutions.

The results of loading alumina balls with $\mathrm{CuSO}_{4}$ solutions are shown in Tables 12,13,14, and 15. The first set of experiments used $\mathrm{CuSO}_{4}$ solution saturated at room temperature $[17.0 \mathrm{~g}$ $\mathrm{CuSO}_{4}$ per $100 \mathrm{~g}$ saturated solution, solution density $1.198 \mathrm{~g} / \mathrm{mL}$ at $20^{\circ} \mathrm{Cl}$. The second used a solution saturated at $42^{\circ} \mathrm{C}$, and the final set a solution saturated at $60^{\circ} \mathrm{C}$.

The cupric sulfate solution soaked alumina balls were the dried. The level of hydration of the cupric sulfate depends strongly on the drying temperature. The dehydration reactions are: 


\begin{tabular}{lcc} 
& \multicolumn{1}{c}{$\mathrm{K}_{373}$} & $\mathrm{~K}_{423}$ \\
$\mathrm{CuSO}_{4} \cdot 5 \mathrm{H}_{2} \mathrm{O} \ldots-\ldots \mathrm{CuSO}_{4} \cdot 3 \mathrm{H}_{2} \mathrm{O}+2 \mathrm{H}_{2} \mathrm{O}(\mathrm{g})$ & $0.94(\mathrm{~atm})^{2}$ & $6.0(\mathrm{~atm})^{2}$ \\
$\mathrm{CuSO}_{4} \cdot 3 \mathrm{H}_{2} \mathrm{O} \rightarrow-\ldots \mathrm{CuSO}_{4} \cdot \mathrm{H}_{2} \mathrm{O}+2 \mathrm{H}_{2} \mathrm{O}(\mathrm{g})$ & $0.52(\mathrm{~atm})^{2}$ & $41.5(\mathrm{~atm})^{2}$ \\
$\mathrm{CuSO}_{4} \cdot \mathrm{H}_{2} \mathrm{O} \ldots \mathrm{CuSO}_{4}+\mathrm{H}_{2} \mathrm{O}(\mathrm{g})$ & $4.99 \times 10^{-3} \mathrm{~atm}$ & $7.96 \times 10^{-2} \mathrm{~atm}$
\end{tabular}

These equilibrium constants were calculated from data in a standard reference. 11 The equilibrium constant subscripts are the temperatures in Kelvins $\left[100^{\circ} \mathrm{C}\right.$ and $150^{\circ} \mathrm{C}$, respectively]. The equilibrium constants and heats of reaction were calculated at $298 \mathrm{~K}$. and then the equilibrium constants at the other temperatures were calculated using the integrated Clausius-Clapeyron equation,

$$
\ln \left(K_{T 2} / K_{T 2}\right)=(\Delta H / R)\left[\left(T_{2}-T_{1}\right) / T_{2} T_{1}\right]
$$

This assumes that the heats of dehydration are constant over the temperature range of integration.

Experimental tests of the dehydration of cupric sulfate hydrates are in general agreement with these estimated equilibrium constants. However, the removal of the last water of hydration is said to be gradual over a wide range of temperature. ${ }^{12}$ The cupric sulfate/alumina materials produced in this work must either never be completely dehydrated or they re-absorb moisture on cooling, because these materials always have a dark green color, while anhydrous cupric sulfate is reported to be nearly white. Re-absorption of water must be considered likely, since anhydrous cupric sulfate has been used as a desiccant. ${ }^{13}$

Water re-absorption is sure to add to the variability of the copper analyses of the material which contains cupric sulfate. Samples will gain weight, depending upon variations in laboratory relative humidity and the time for which the ground sample is exposed to the air before digestion. 


\section{Conclusions}

1. The PETC cupric nitrate process has been used to prepare $\mathrm{CuO} / \mathrm{Al}_{2} \mathrm{O}_{3}$ balls with copper content in the desired range of 6.5 to $7.5 \mathrm{wt} . \%$ [as $\mathrm{Cu}$ ]. The materials based on Alcoa Alumina B had good chemical reactivity, but were less attrition resistant than PETC's baseline material.

2. Suitable absorbent can also be made by loading Alcoa alumina balls with cupric sulfate solutions of the proper concentration. The Alcoa Alumina B based materials had good chemical reactivity, and the regeneration rate increased after first cycle.

3. The "special" (Alcoa Alumina A) alumina balls [an additive to strengthen the walls] have good mechanical strength, but their chemical reactivity declines rapidly after a few cycles of absorption and regeneration. The loss of reactivity occurs whether the copper starts as $\mathrm{CuO}$ or $\mathrm{CuSO}_{4}$.

4. Reaction of ammoniacal cupric sulfate with activated alumina balls does not deposit enough copper unless very large solution volumes are used per unit weight of alumina balls.

\section{Recommendations}

1. Other additives should be tested for improving Alcoa alumina ball strength.

2. Improved prediction of the copper loading levels should be sought by using the "incipient wetness" technique, so that the amount of copper solution can be related to the weight of alumina balls impregnated. 


\section{References}

1. Yeh, J. T.; Demski, R. J.; Strakey, J. P., and Joubert, J. I.; Environmental Progress, v4, No. 4 [1985], pp. 223-228.

2. Strohmeier, B. R.; Leyden, D. E.; Field, R. S.; and Hercules, D. M.; Loumal of Catalysis, v.94 (1985), pp. 514-530.

3. Wefers, K.; and Misra, C.; Oxides and Hydroxides of Aluminum, Alcoa Technical Paper 19, Revised Alcoa Laboratories, Alcoa Center, PA, 1987, pp. 46-48, Figure 4.4.

4. Lowe, J. A. and W. H. Quayle, Alcoa Internal Communication.

5. Baes, C.F.; and Messmer, R. E.; The Hydrolysis of Cations, Krieger, Malabar, FL, 1986 .

6. a) Discussion at meeting at PETC June 30, 1994; b) Centi, G.; B. K. Hodnett, P. Jaeger, C. Macken, M. Marella, M. Tomaselli, G. Paratto, and S. Perathoner, L. Mater. Res, v. 10 [1995], pp. 553-561:

7. Pennline, H. W.; Hoffman, J. S.; Markussen, J. M.; Hedges, S. S.; Baltrus, J.; Pollack, S.; and Martello, D.; PETC Interim Report: May 1995 Alcoa CRADA PC-93007, June 14, 1995.

8. Chemical Marketing Reporter, August 01, 1994.

9. Solubilities Inorganic and Metal-Organic Compounds, W. F. Linke, American Chemical Society, Washington, DC, 1958, v.1, p. 965.

10. Hudson, L. K.; and Marshall, E. E.; Alcoa Proprietary Data.

11. Wagman, D. D., et al.; L. Chem. Phys. Ref. Data, v. 11, suppl. 2, 1982, pp. 2-155, 2-156, and 2-38. 

Table 1

Properties of the Original Alumina Balls

\begin{tabular}{|c|c|c|c|c|}
\hline $\mathrm{Al}_{2} \mathrm{O}_{3}$ Type & Size, inch & $\begin{array}{c}\text { Surface Area, } \\
\mathrm{m}^{2} / \mathrm{g}\end{array}$ & $\begin{array}{c}\text { Pore Volume, } \\
\mathrm{cc} / \mathrm{g}\end{array}$ & $\begin{array}{c}\text { Crush Strength, } \\
\mathrm{lb}\end{array}$ \\
\hline Alumina A & $1 / 16$ & 318 & 0.577 & $15^{*}$ \\
\hline Alumina B & $1 / 16$ & 362 & 0.568 & 9 \\
\hline Alumina B & $1 / 8$ & 359 & $0.5071 \#$ & $19^{*}$ \\
\hline Alumina C & $1 / 8$ & 327 & 0.568 & 28. \\
\hline Alumina C & $1 / 8$ & 270 & 0.550 & 18.4 \\
\hline Alumina C & $1 / 4$ & 326 & 0.571 & 54.5 \\
\hline
\end{tabular}

*) Vidalia result.

\#) From water absorption; the rest are from the formula pore volume $=1 /$ bulk density $1 /$ helium density. (Bulk density is the number reported by the mercury porosimetry analysis.)

Note: Aluminas A, B, and C are all Alcoa products. 


\section{PROTECTED CRADA IKFORMATION}

Table 2

Effect of Increased Activation Temperature on Ball Strength - 1/8 inch Alumina D

\begin{tabular}{|c|c|c|}
\hline $\begin{array}{c}\text { Surface Area, } \\
\mathrm{m}^{2} / \mathrm{g}\end{array}$ & Crush Strength, lb & $\begin{array}{c}\text { Hg Intrusion Volume, } \\
\mathrm{cc} / \mathrm{g}\end{array}$ \\
\hline 327. & 28.0 & 0.4569 \\
\hline 270. & 18.4 & 0.5538 \\
\hline 150. & 13.9 & 0.6045 \\
\hline
\end{tabular}


Table 4

Preparation Conditions for Alumina Balls Used in $\mathrm{CuO} / \mathrm{Al}_{2} \mathrm{O}_{3}$ Preparation

$\begin{array}{ccc}\text { Sample } \mathrm{No}_{0} & \mathrm{Al}_{2} \mathrm{O}_{3} \text { Ball Size inch } & \begin{array}{c}\text { Soak Time in } \\ \mathrm{Cu( \textrm {NO } _ { 3 } ) _ { 2 } . \mathrm { hr }} .\end{array} \\ 25351-27 & 0.125 & 1.25 \\ 25351-28 & 0.125 & 1.25 \\ 25351-46 & 0.0625 & 1.0 \\ 25351-63 & 0.25 & 8.0\end{array}$




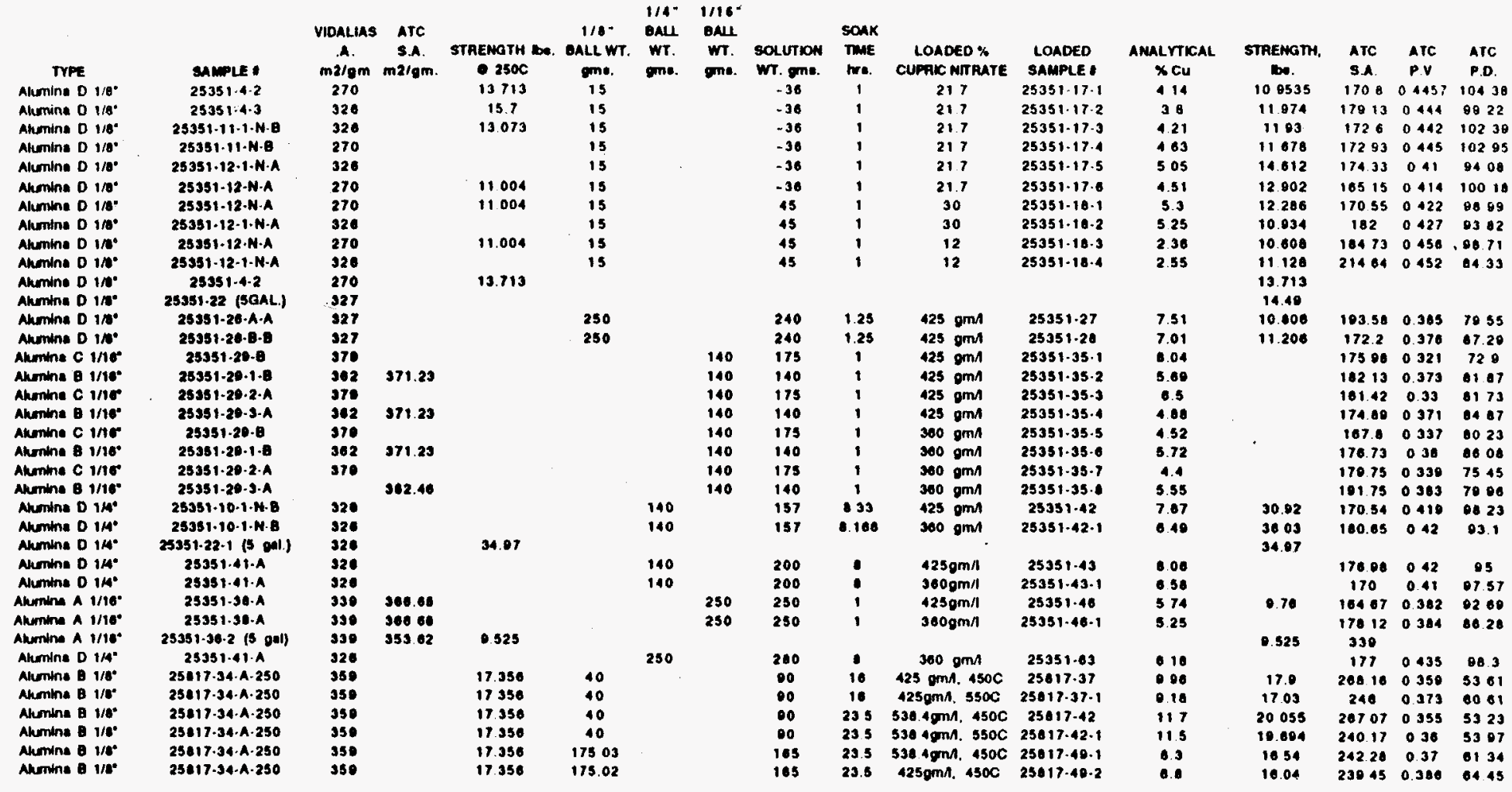

NOTES:

1. CUPAIC NITAATE (FISHER SCI. $1 \mathrm{C}-467$ LOT B71132)

2. CUPAIC NITAATE SOLUTION $21.7 \% ; 200 \mathrm{gm} ., 43.4 \mathrm{gm}$. CUPAIC NITRATE ANO $156 \mathrm{gm}$. WATER

3 (SUGGEST EXTENONG SOAK TME BECAUSE OF LARGER BALL DIAMETERT) SOME BALLS WERE AEMOVED AFTEA $30 \mathrm{MIN}$. ANO

CPACKED OPEN TO OBSERNE DXTENT OF PENETPUTION.

THE BALLS WERE PENETPATED ABOUT HALF WAY.

THE SOAK WAS EXTENDED TO IHA.

4. THE A BALLS APPEARED TO HAVE ABOUT TOTAL. PENETPATION ANO.

LESS PENETRATION FOA THE B AND MUCHLESS FOR UNTREATED AFTER ONE HOUA SOAK.

5. FUPNACE CYCLE: 149C FOR 16hm. PUMP 20CMIN. TO $650 \mathrm{C}$ AND HOLD FOR Ghrs.

6. CUPAIC NITPATE SOLUTION $\bullet 30 \%, 100 \mathrm{gm}$. BATCH-30gm. CUPAIC NITAATE ANO $70 \mathrm{gms}$. D.I. H2O

7. CUPAIC NITPATE SOLUTION @ 12\%, $100 \mathrm{gm}$ BATCH.12gm CUPAIC NITPATE AND

8. SAMPLE PREPEPUTION: WEIGHOUT BALLS, WEICHOUT CUPPIC NITPATE SOLUTION,

THEN PLACE BALLS N SOLUTION, LET STAND ONE HOUR, THEN PLACE CONSISTS IN SCREEN ANO REMOVE

EXCESS BY TAPNG SCAEEN ON DAY TOWEL WASH ANO OAY THE PORCELAN DISH AND RETURN BALLS TO SAME.

(SUGGESTION DIP SCREEN WITH BALIS FROM SOLUTION N D.1. HEO TO REMOVE EXCESS OUPRIC NITPATE?)

9. OBSEFNATION OF BALLS AFTER DRY CYCLE: 12\% BALLS AAE BLUE.GREEN AND 30\% BALLS DARK GREEN.

THE BALLS WERE SMASHED ANO THE INSIDE NSPECTED WITH A MAGNIFYING GLASS

THE: 30\% BALLS ARE TOTALLY IMPAEGNATED AND THE $12 \%$ BALLS ARE NOT TOTALY IMPPEGNATED

10. SAMPLES 25017.37 \& 37-1 CHANGED CALCINATION TEMP. FROM 650C (NOTE 5.). ALSO, NFW BALL SIZE LO-350 1/8.

11. SAMPLES 25017.42 \& 42.1 CHANGEO LOADING TO $538.4 \mathrm{gms} /$ CU(NO3)2. LOAOING REQUIRES $25 \%$ BY WT. EXCESS OF CU(NO3)2 PER GRAM OF ALUMINA 


\begin{tabular}{|c|c|}
\hline \multirow{2}{*}{ 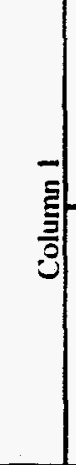 } & 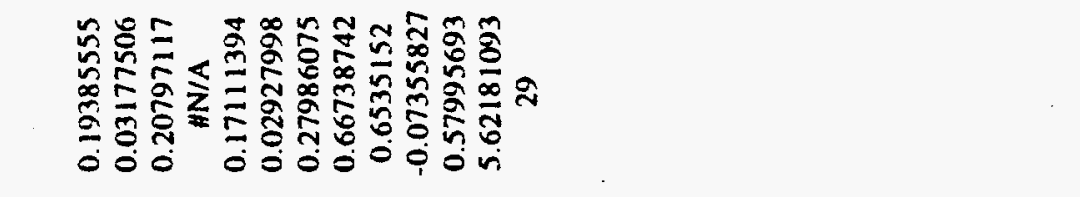 \\
\hline & 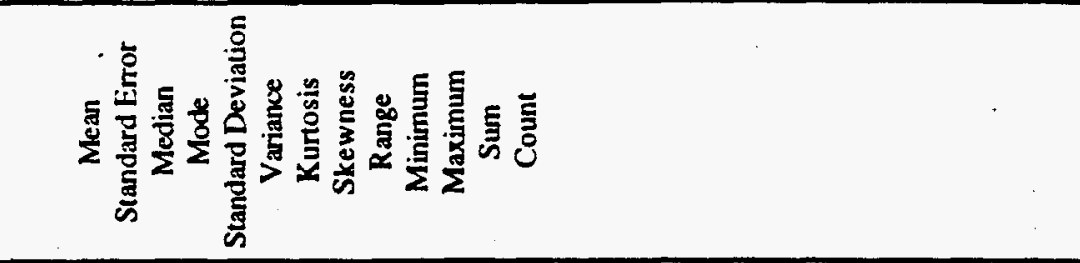 \\
\hline 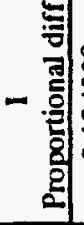 & 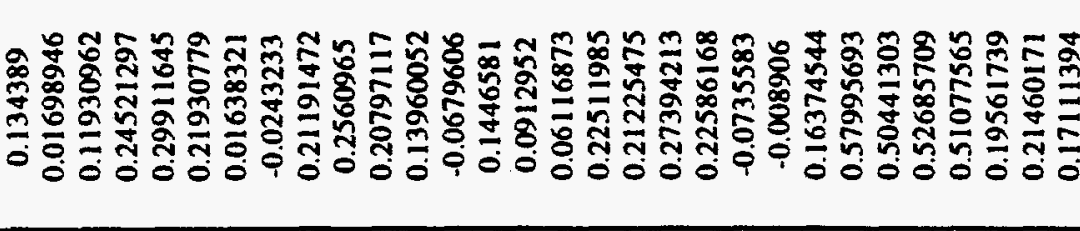 \\
\hline 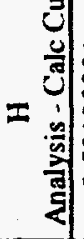 & 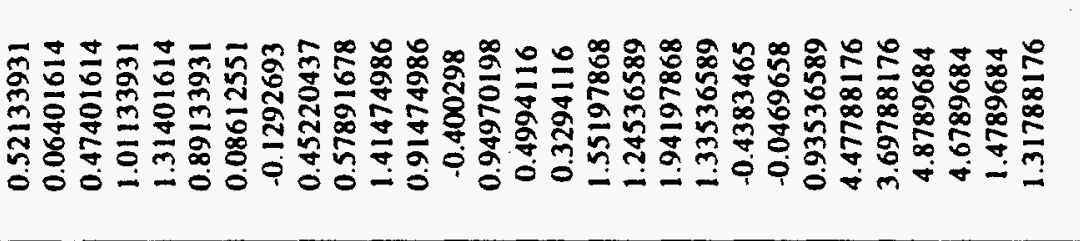 \\
\hline 章 & 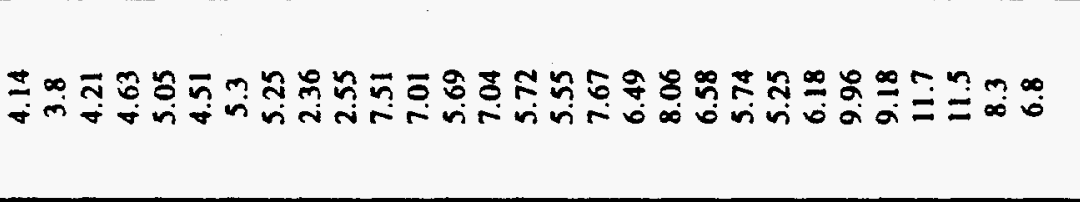 \\
\hline 证 & 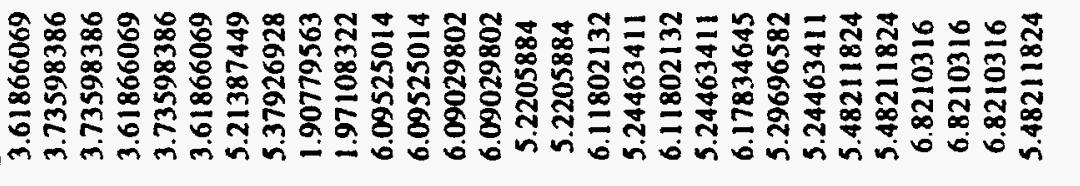 \\
\hline (2) & 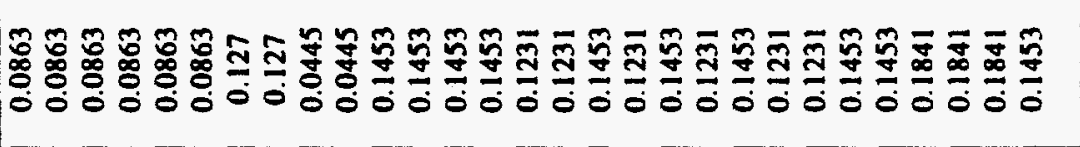 \\
\hline 㫄 & స̂ં \\
\hline है & 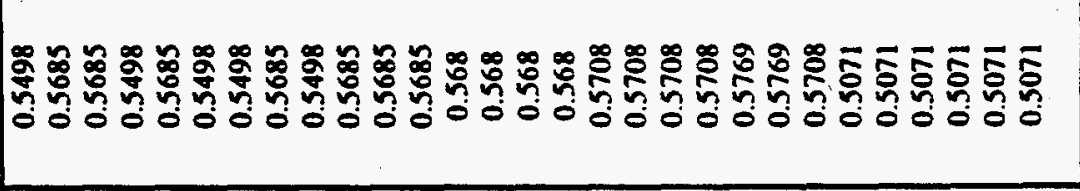 \\
\hline ह & 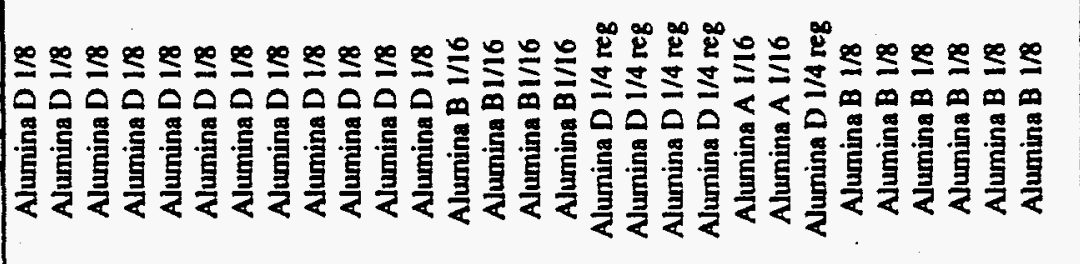 \\
\hline 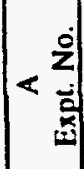 & 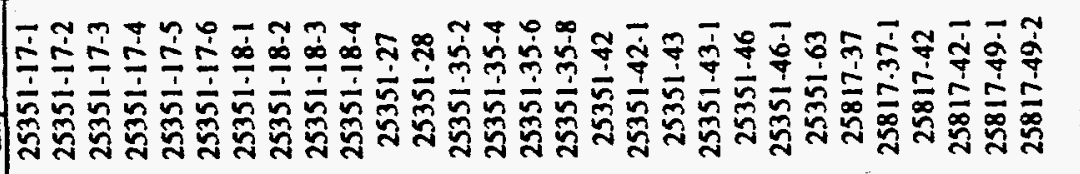 \\
\hline
\end{tabular}


Table 7

Properties of $\mathrm{CuO} / \mathrm{Al}_{2} \mathrm{O}_{3}$ Samples Supplied to PETC

\begin{tabular}{|c|c|c|c|c|c|c|}
\hline Sample No. & Percent Cu & $\begin{array}{c}\text { Average } \\
\text { Crush } \\
\text { Strength, } \\
\mathrm{lb}^{\#}\end{array}$ & $\begin{array}{c}\text { Crush } \\
\text { Strength } \\
\text { s.d. }\end{array}$ & $\begin{array}{c}\mathrm{N}_{2} \text { Surface } \\
\text { Area, } \\
\mathrm{m}^{2} / \mathrm{g}\end{array}$ & $\begin{array}{c}\text { Pore } \\
\text { Volume, } \\
\mathrm{cc} / \mathrm{g}\end{array}$ & $\begin{array}{c}\text { Average } \\
\text { Pore Dia., } \\
\mathrm{A}^{*}\end{array}$ \\
\hline $25351-46-1$ & 5.25 & 9.76 & 3.34 & 178.1 & 0.384 & 86.3 \\
\hline $25351-35-2$ & 5.69 & & & 182.1 & 0.373 & 81.9 \\
\hline $25351-35-3$ & 6.50 & & & 161.4 & 0.33 & 81.7 \\
\hline
\end{tabular}

*) B.E.T. 4V/A

\#) Average of 20 balls

The crush strength data is for a similar batch made on the same base alumina.

The abrasion of this material [25351-46-1] was $0.042 \%$, compared with $0.035 \%$ for the untreated base alumina balls.

Total Pore Volume [TPV]:

$$
\begin{aligned}
\text { TPV } & =1 / \text { bulk density }-1 \text { /helium density } \\
& =1 / 1.1059-1 / 3.18=0.5898
\end{aligned}
$$

The bulk density number is the value reported in the mercury porosimetry results. The helium density is the value from Analytical Chemistry Division J.0. 94-102016.

Mercury Porosimetry Results:

Total intrusion volume $=0.1252 \mathrm{~mL} / \mathrm{g}$. 
Table 8

Percent Copper in $\mathrm{CuO} / \mathrm{Al}_{2} \mathrm{O}_{3}$

Analyses by Different Labs and Methods

\begin{tabular}{|c|c|c|c|c|c|c|c|}
\hline Sorbent No. & Alcoa & PETC & Contract & PETC [1] & $\begin{array}{c}\text { Alcoa [1] } \\
\mathrm{H}_{2} \mathrm{O}_{2}\end{array}$ & $\begin{array}{c}\text { Alcoa [1] } \\
\text { Fusion }\end{array}$ & $\begin{array}{c}\text { Contract } \\
{[1]}\end{array}$ \\
\hline $25351-46-1$ & 5.25 & 5.2 & 5.64 & 5.0 & 4.78 & 5.91 & 5.14 \\
\hline $25351-35-2$ & 5.69 & 7.1 & 7.82 & 6.0 & 6.27 & 7.24 & 6.52 \\
\hline $25351-35-3$ & 6.5 & $8.3[2]$ & 9.05 & 7.5 & 7.40 & 8.97 & 8.03 \\
\hline
\end{tabular}

[1] Round Robin analyses; Alcoa analyses are all by ICP.

[2] A.A./Alcoa prep; 8.46, 6.2, 8.4, 8.38. 
Table 10

\section{$\mathrm{CuO} / \mathrm{Al}_{2} \mathrm{O}_{3}$ Prepared by the Copper Nitrate} Method for Higher Surface Area

\begin{tabular}{|c|c|c|c|c|c|c|}
\hline Sample Number & $\begin{array}{c}\text { Wt.\% } \\
\mathrm{Cu}\end{array}$ & $\begin{array}{c}\text { Average } \\
\text { Crush } \\
\text { Strength, } \\
\text { lb @ }\end{array}$ & $\begin{array}{c}\text { Crush } \\
\text { Strength } \\
\text { Standard } \\
\text { Deviation, } \\
\text { lb. }\end{array}$ & $\begin{array}{c}\text { Nitrogen * } \\
\text { Surface } \\
\text { Area, } \\
\mathrm{m}^{2} / \mathrm{g}\end{array}$ & $\begin{array}{c}\text { Pore* } \\
\text { Volume, } \\
\mathrm{cc} / \mathrm{g}\end{array}$ & $\begin{array}{c}\text { Average * } \\
\text { Pore } \\
\text { Diameter, } \\
\text { A\# }\end{array}$ \\
\hline $25817-37$ & 9.96 & 17.9 & 4.2 & 268.2 & 0.359 & 53.6 \\
\hline $25817-37-1$ & 9.18 & 17.0 & 4.5 & 246.0 & 0.372 & 60.6 \\
\hline $25817-42$ & 11.7 & 20.1 & 4.1 & 267.0 & 0.355 & 53.2 \\
\hline $25817-42-1$ & 11.5 & 19.7 & 5.2 & 240.2 & 0.360 & 54.0 \\
\hline
\end{tabular}

*) From 20 point nitrogen sorption analysis.

\#) BET 4V/A.

@) Average of 20 balls.

The surface areas of all of these samples are considerably higher than the surface areas of samples 25351-35-1 and 25351-35-4 [175.98 and $174.89 \mathrm{~m}^{2} / \mathrm{g}$, respectively] which you previously tested; this is the result of a change in the processing conditions designed to improve the crush strength of the $\mathrm{CuO} / \mathrm{Al}_{2} \mathrm{O}_{3}$ balls. The crush strength values are very close to the crush strength of the original alumina balls used to prepare these samples. The copper levels reported are above the levels which we intended to obtain.

The samples $25817-37$ and $25817-42$ were calcined at $450^{\circ} \mathrm{C}$, and the samples $25817-37-1$ and $25817-42-1$ were calcined at $550^{\circ} \mathrm{C}$. 
Table 11

Ammoniacal Copper Sulfate Reaction

With Alumina Balls

\begin{tabular}{|c|c|c|c|c|c|}
\hline Sample No. & $\mathrm{Al}_{2} \mathrm{O}_{3}$ Type & $\begin{array}{c}\mathrm{Rx} \text { Temp., } \\
{ }^{\mathrm{C}}\end{array}$ & $\mathrm{Al}_{2} \mathrm{O}_{3}, \mathrm{~g}$ & Soln., $\mathrm{mL}$ & $\begin{array}{c}\% \mathrm{Cu} \text { on } \\
\mathrm{Al}_{2} \mathrm{O}_{3}\end{array}$ \\
\hline $25351-57-1$ & Alumina A & 50 & 2.1 & 400 & 6.4 \\
$25351-57-2$ & Alumina A & 50 & 2.1 & 400 & 5.8 \\
$25351-57-3$ & Alumina B & 50 & 2.1 & 400 & 9.3 \\
$25351-57-4$ & Alumina B & 50 & 2.1 & 400 & 5.9 \\
& & 50 & 62.5 & 250 & 2.25 \\
$25351-66-1$ & Alumina A & 52 & 62.5 & 250 & 2.38 \\
$25351-66-2$ & Alumina A & 22 & 62.5 & 250 & 2.58 \\
$25351-66-3$ & Alumina B & 50 & 62.5 & 250 & 2.47 \\
$25351-66-4$ & Alumina B & 22 & 50 & 400 & 3.79 \\
$25352-75-1$ & Alumina A & 22 & 40 & 400 & 3.85 \\
$25351-75-2$ & Alumina A & 22 & 50 & 400 & 3.74 \\
$25351-75-1$ & Alumina B & 22 & 40 & 400 & 3.95 \\
$25351-75-4$ & Alumina B & 22 & &
\end{tabular}

Notes: 1] Each solution was $1.0 \mathrm{M}$ in ammonia and $0.25 \mathrm{M}$ in copper (II).

2] All of the reactions were run 24 hours with constant agitation.

3) Initial conditions taken from Alcoa data, by J. A. Lowe and W. H. Quayle.

4] The balls were washed with D.I. water and dried at ${ }^{\circ} \mathrm{C}$ before analysis. 
Table 12

COPPERSULFAIESAMPLES

COPPER AMINE SULFATE SAMPLES

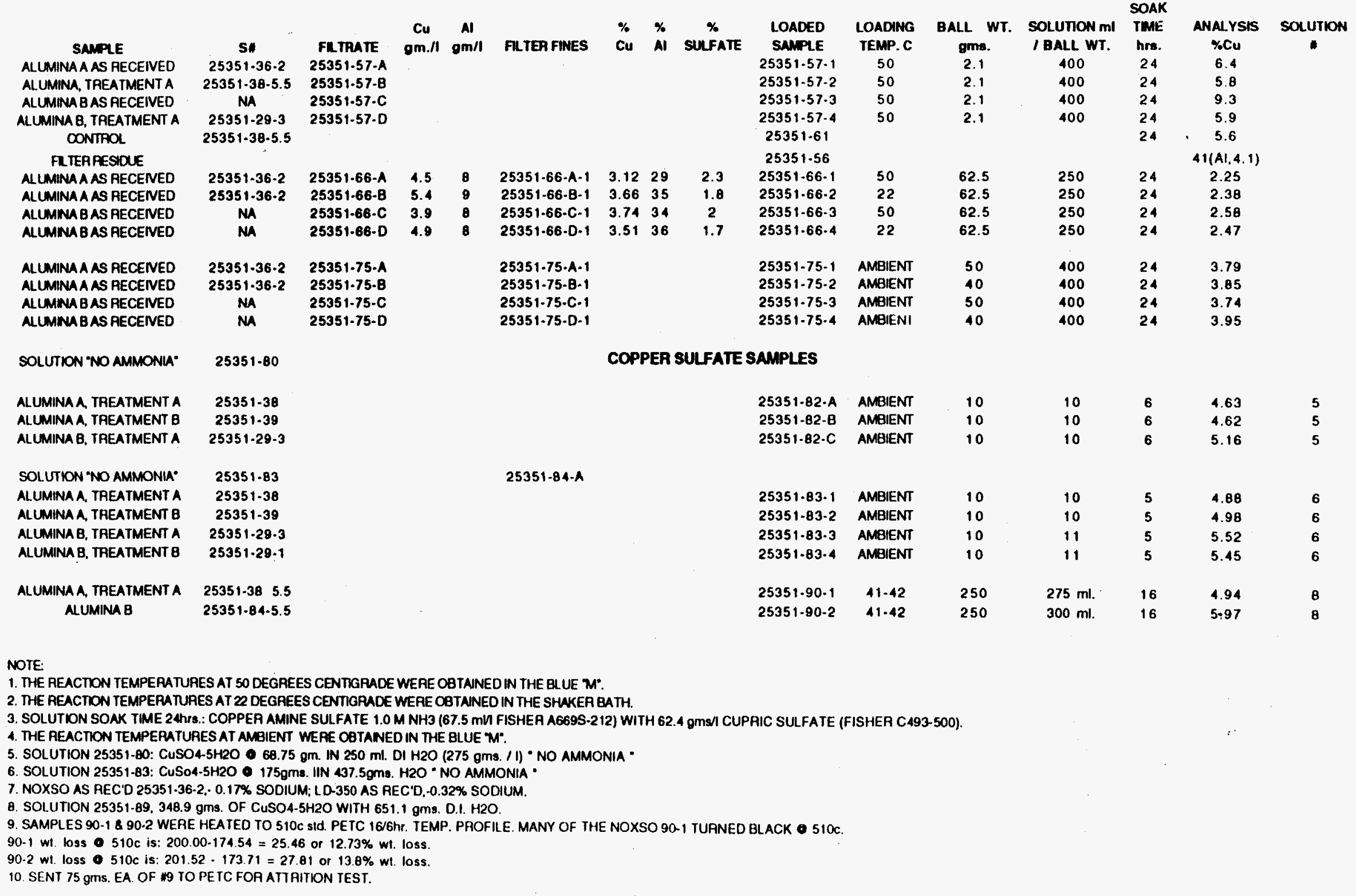


Table 13

Alumina Loaded with Copper Sulfate

\begin{tabular}{|c|c|c|c|}
\hline Sample Number & Alumina Type & Wt.\% Cu & $\begin{array}{c}\text { Wt.\% Cu When } \\
\mathrm{CuO}^{*}\end{array}$ \\
\hline $25351-83-1$ & Alumina A & 4.88 & 5.67 \\
\hline $25351-83-2$ & Alumina A & 4.98 & 5.74 \\
\hline $25351-83-3$ & Alumina B & 5.52 & 6.48 \\
\hline $25351-83-4$ & Alumina B & 5.45 & 6.38 \\
\hline
\end{tabular}

Notes: 1] The aluminas were all $1.5 \mathrm{~mm}$ [ $7 \times 14 \mathrm{mesh}]$.

2] Each alumina was soaked for 5 hours in saturated [room temperature] aqueous $\mathrm{CuSO}_{4} \cdot 5 \mathrm{H}_{2} \mathrm{O}$.

3] The saturated balls were dried overnight at $100^{\circ} \mathrm{C}$ overnight at $<40$ torr.

* Calculated assuming the complete conversion of $\mathrm{CuSO}_{4}$ to $\mathrm{CuO}$. 
Table 14

Samples Prepared at $42^{\circ} \mathrm{C}$

\begin{tabular}{|c|c|c|c|}
\hline Sample Number & Base Alumina Type & Wt.\% Copper & $\begin{array}{c}\text { Wt.\% Cu } \\
\text { When CuO* }\end{array}$ \\
\hline $25351-90-1$ & Alumina A & 4.94 & 5.69 \\
\hline $25351-90-2$ & Alumina B & 5.97 & 7.11 \\
\hline
\end{tabular}

*) This assumes conversion of $\mathrm{CuSO}_{4} \cdot 5 \mathrm{H}_{2} \mathrm{O}$ to $\mathrm{CuO}$, and allows for the removal of $\mathrm{SO}_{3}$ and $5 \mathrm{H}_{2} \mathrm{O}$ from the material.

The copper sulfate is still hydrated to some extent, even though the samples were dried overnight at $100^{\circ} \mathrm{C}$ with continuous pumping to give 40 torr pressure. 
Table 15

Loading Alumina Balls with Cupric Sulfate at $60^{\circ} \mathrm{C}$ :

Effect of Ball Size

\begin{tabular}{|c|c|c|c|c|c|}
\hline Sample No. & Ball Size \& Type & $\begin{array}{c}\text { Pore } \\
\text { Volume, } \\
\text { cc/g* }\end{array}$ & $\begin{array}{c}\text { CuSO4, } \\
\text { g/L }\end{array}$ & $\begin{array}{c}\text { \% Cu } \\
\text { Reported }\end{array}$ & $\begin{array}{c}\text { \% Cu, Oxide } \\
\text { Basis }^{\#}\end{array}$ \\
\hline $25817-18-1$ & 1/16, Alumina A & $0.564^{* *}$ & 315 & 5.82 & 6.39 \\
\hline $25817-18-2$ & $1 / 8$, Alumina D & 0.5685 & 315 & 5.75 & 6.31 \\
\hline $25817-18-3$ & $1 / 4$, Alumina D & 0.5708 & 315 & 6.37 & 7.06 \\
\hline $25817-18-4$ & 1/16, Alumina A & $0.564^{* *}$ & 381 & 5.91 & 6.50 \\
\hline $25817-18-5$ & 1/8, Alumina D & 0.5685 & 381 & 6.56 & 7.19 \\
\hline $25817-18-6$ & 1/4, Alumina D & 0.5708 & 381 & 7.33 & 8.26 \\
\hline
\end{tabular}

*) Data from Vidalia Works.

**) Based on water sorption by balls previously given pretreatment $\mathrm{A}$ and dried at $250^{\circ} \mathrm{C}$ under vacuum.

\#) $\% \mathrm{Cu}$ in alumina balls saturated with $\mathrm{CuSO}_{4}$ solution and dried at $100^{\circ} \mathrm{C}$ under aspirated vacuum.

\#) Calculated \% $\mathrm{Cu}$ if the copper were converted to $\mathrm{CuO}$, assuming that the sulfate was present as $\mathrm{CuSO}_{4} \cdot \mathrm{H}_{2} \mathrm{O}$. 
Appendix I

\section{ALCOA-PETC CRADA PC-93007 STATEMENT OF WORK}

\section{Qbjective}

Alcoa will attempt to develop an improved sorbent that can be used in the Copper Oxide Flue Gas Cleanup Processes (specifically the Moving-Bed Process). PETC will provide some laboratory assistance to Alcoa in return for a well-characterized sorbent and a large batch of an improved sorbent that could be used in future process developmental unit (PDU) studies at PETC. The work will be divided into three phases.

\section{Introduction}

The Copper Oxide Processes that have been researched in the flue gas cleanup area can simultaneously remove both $\mathrm{SO}_{2}$ and $\mathrm{NO}_{x}$ pollutants from the flue gas produced by combusting coal in a utility boiler. The sorbent that has been traditionally used in this work consists of $1 / 16$ inch spheres of gamma alumina impregnated with copper oxide. To date, the best sorbent tested (Sorbent $A$ ) is manufactured by a catalyst company.

Previous information will establish a benchmark with Sorbent A with respect to reactivity performance and attrition performance and will be used as a comparison for any other proposed sorbents. Alcoa will attempt to develop a copper oxide/alumina sorbent that will, as a minimum, meet the qualifications of Sorbent $\mathrm{A}$. If successful, Alcoa may be able to provide a potentially marketable, improved sorbent for the Copper Oxide Processes.

\section{Experimental Approach}

\section{Phase I}

Alcoa will fabricate a sorbent according to the specifications of PETC: A PETC-formulated impregnation technique for deposition of copper oxide within alumina will be followed. The copper content, the alumina material, the size of beads, and the preparation technique including calcination will be recommended by PETC. Alcoa will provide an alumina sphere made by a proprietary process. The exact chemical composition of the sphere (i.e., the active adsorbent 
support) is also proprietary. If Alcoa devises a better technique, this technique may be used provided both parties agree to such changes in the technique. Alcoa will determine the copper loading and the uniformity of the impregnation (after activation) via analytical techniques. Tests by Alcoa for the physical properties of the sorbent product will include but not be limited to surface area, $\mathrm{Hg}$ pore volume, bulk density, compressive strength (e.g., ASTM D-4179), abrasion resistance, and attrition resistance determination. Alcoa will report these physical properties, bulk copper and alumina content, and uniformity of impregnation.

PETC will perform up to five microbalance or TGA tests with the above candidate sorbent to characterize the reactivity of the improved sorbent. Simulated flue gas will be used in these tests. Also, PETC will perform up to five air-jet attrition tests for determination of attrition resistance of the candidate sorbent.

Each party will provide the other with a brief, timely written description of the results from this phase of the CRADA.

\section{Phase II}

Results from the previous physical and reactivity characterization tests of Phase I will determine whether a large batch of sorbent should be fabricated by Alcoa. If these previous results are favorable and the DOE/PETC commits to doing the testing on the PDU-scale, Alcoa will provide at no cost to PETC a $2000 \mathrm{lb}$ (approximate) batch of the final improved sorbent for eventual testing in the Moving-Bed Life-Cycle Test system (LCTD). Alcoa will need to provide the scaleup necessary to go from the small-scale sorbent fabrication/activation done in Phase I to the large batch in Phase II. Also, Alcoa will perform physical and chemical analyses on representative samples of sorbent produced during the large batch production as a form of quality control.

PETC will perform microbalance or TGA studies on some of these representative samples of sorbent produced during the large batch production. Ultimately, PETC will investigate the performance of the large batch sorbent in the LCTS for a minimum of one week (five continuous days) of operation.

A brief, timely written summary of the proceedings of this phase will be done for each task hy the responsible party. 
Phase III

This phase will be similar to Phase I. However, two different synthesis routes for the fabrication of the sorbent will be investigated by Alcoa (the routes would be proprietary). The synthesis methods used are excluded informatton. Alcoa will disclose the physical properties, copper and $\mathrm{Al}_{2} \mathrm{O}_{3}$ content. Other additives in the adsorbent will be excluded information. The characterization of the physical and chemical properties by Alcoa would also be the same as in Phase I. If the sorbents produced by either or both of these synthesis routes have been acceptable physical and chemical properties, then PETC would evaluate the sorbent(s) for chemical reactivity in the TGA or microbalanceunit.

Each party will provide the other with a brief, timely written description of this phase of the CRADA.

If the timing in the CRADA were such that Phase III was conducted before Phase II and that positive results from Phase III directed the research to follow one of the new proprietary synthesis routes, then fabrication of the large batch of sorbent of Phase II could use this new synthesis route, provided PETC and Alcoa agree to this.

Alcoa will provide PETC all results of their work with the sorbent, except for excluded data and proprietary substrate routes of fabrication as described in this Scope of Work and in Article VIII.D. Proprietary information can be provided to PETC as it relates to the sorbent investigation. However, PETC will protect the proprietary information in accordance with Article VII - Obligations as to Proprietary Information. Alcoa will also provide a prospectus related to the projected cost to the user of the sorbent for future commercial supply. PETC shall provide estimated annual commercial sorbent usage rates.

PETC will report to Alcoa its data pertaining to the sorbent's reactivity and physical property studies. PETC will also report to Alcoa the results of the LCTS tests with the Alcoa sorhent.

All results can be published in the open literature, except for any proprietary information.

Alcoa will not be required to disclose or patent it Proprietary Information, but will abide by its obligations as to proprietary information as set forth in Article VII. 
Environmental. Health and Safety

Alcoa will furnish PETC with Material Safety Data Sheets and any other pertinent environmental, health and safety information pertaining to the substrate. PETC will be responsible for the retum to Alcoa of all unused and spent sorbent fabricated for the LCTS testing. 


\section{CRADA COST EVALUATION}

\section{Phase I}

\section{Alcoa}

Preparation of sorbent and chemical and physical analyses

PETC

Microbalance testing.

Air-jet attrition testing.

Phase II

Alcoa

Preparation of a large (2000 lb) batch of sorbent

PETC

Microbalance testing

LCTS investigation

\section{Phase III}

Alcoa

Preparation of two sorbents by new synthesis route and chemical and physical analyses

PETC

Microbalance testing

Air-jet attrition testing

\section{Cost Summary}

Total PETC CRADA Contribution $\$ 50430$

Total Alcoa CRADA Contribution $\$ 48000$

Estimated Total CRADA Value. $\$ 98430$ 
Appendix II

\section{Calculation of Copper Loading Levels From Alumina Ball Pore \\ Volume and Copper Salt Solution Concentration}

\section{1] Pore Volume Measurement}

\section{a] From Helium Density and Mercury Porosimetry Bulk Density}

This method requires the "bulk density" number reported in a mercury porosimetry analysis and the helium density of the same material.

Let $\rho_{\text {bulk }}=$ bulk density reported by the mercury porosimeter

$\rho \mathrm{He}=$ Helium density

then

$$
\text { pore volume }=p v=1 / \rho \text { bulk }-1 / \rho \mathrm{He}
$$

b] By Water Impregnation

(1) The balls to be tested are dried at $250^{\circ} \mathrm{C}$ under a water aspirator vacuum for at least two hours.

(2) Weigh out a sample of balls as quickly as the weighing can be done accurately (to minimize water pick up from the air).

s.

(3) Place the weighed sample of balls in one gram of de-ionized water per gram of balls. Allow the balls to soak for two hours for $1 / 8$ inch or smaller balls; soaking should last six hours for $1 / 4$ inch balls.

(4) Drain the excess water from the balls and blot the surface of the balls with lint-free tissue to remove the surface moisture.

(5) Weigh the wet balls. 
(6) Dry the wet balls again at $250^{\circ} \mathrm{C}$ for two hours under vacuum and weigh again to check the string weight.

(7) Calculate the weight of water imbibed by one gram of balls. This is the pore volume, since we assume that the density of the water is $1.00 \mathrm{~g} / \mathrm{mL}$.

\section{2] Calculation of Copper Loading}

The pore volume of the alumina balls and the copper salt solution concentration [weight or moles per unit volume] must be known. This prediction is base on the assumption that the balls will absorb a volume of copper salt solution equal to the pore volume of the balls.

The second assumption is that all of the copper in the copper salt solution will remain is the balls when the impregnated balls are dried and/or calcined.

\section{a] $\mathrm{CuO}$ Case}

The results are reported as per cent elemental copper $[\mathrm{Cu}]$ even though the copper is present as $\mathrm{CuO}$, so the result can be calculated as

$$
\begin{gathered}
\text { mmoles } \mathrm{Cu} / \mathrm{g} \mathrm{Al}_{2} \mathrm{O}_{3}=[\text { molarity of } \mathrm{Cu}] \times\left[\mathrm{mL} \text { pore } \mathrm{V} / \mathrm{g} \mathrm{Al}_{2} \mathrm{O}_{3}\right] \\
\% \mathrm{Cu}=\{[\mathrm{mmoles} \mathrm{Cu} \times 0.06354 \mathrm{~g} / \mathrm{mmole} \mathrm{Cu}] /[1.0+\mathrm{mmole} \mathrm{CuO} \times \\
0.07953 \mathrm{~g} / \mathrm{mmole} \mathrm{CuO}]\} \times 100
\end{gathered}
$$

\section{b] $\mathrm{CuSO}_{4}$ Case}

These results are also reported as \% $\mathrm{Cu}$, even though the copper is present as $\mathrm{CuSO}_{4}{ }^{\bullet} \mathrm{H}_{2} \mathrm{O}$. [The state of hydration depends upon the drying temperature and pressure - see page 10]. It is also desirable to report the percent copper when the sorbent has been regenerated to the $\mathrm{CuO}$ form, in order to allow comparison with sorbents made by the copper nitrate process. 
(1) $\% \mathrm{Cu}$ when in the $\mathrm{Cu}$ is present as $\mathrm{CuSO}_{4} \cdot \mathrm{H}_{2} \mathrm{O}$.

$9 \mathrm{Cu}=\left\{\left[\mathrm{CCu} \times\left(\mathrm{mL} / \mathrm{Al}_{2} \mathrm{O}_{3}\right) \times 0.06354 \mathrm{~g} / \mathrm{mmole} \mathrm{Cu}\right] /\left[1.0+\mathrm{C} \mathrm{Cu} \times\left(\mathrm{mL} / \mathrm{Al}_{2} \mathrm{O}_{3}\right) \times\right.\right.$ $\left.\left.0.17761 \mathrm{~g} / \mathrm{mmole} \mathrm{CuSO}_{4} \cdot \mathrm{H}_{2} \mathrm{O}\right]\right\} \times 100$

where $\mathrm{C}_{\mathrm{Cu}}=$ the molarity of the $\mathrm{CuSO}_{4}$ solution used to load the balls

(2) When the sorbent has been regenerated to the $\mathrm{CuO}$ form, the $\% \mathrm{Cu}$ will be [assuming stoichiometric conversion of $\mathrm{CuSO}_{4} \cdot \mathrm{H}_{2} \mathrm{O}$ to $\mathrm{CuO}$ ]:

$\% \mathrm{Cu}=\left(\left[\mathrm{C} \mathrm{Cu} \times\left(\mathrm{mL} / \mathrm{Al}_{2} \mathrm{O}_{3}\right) \times 0.06354 \mathrm{~g} / \mathrm{mmole} \mathrm{Cu}\right] /\left[1.0+\mathrm{C} \mathrm{Cu} \times\left(\mathrm{mL} / \mathrm{Al}_{2} \mathrm{O}_{3}\right) \times\right.\right.$ $0.07953 \mathrm{~g} / \mathrm{mmole} \mathrm{CuO}]$ ] $\times 100$ 


\section{$25351-17-1$}

Figure 1 EDX Dot Map of 25351-17-1

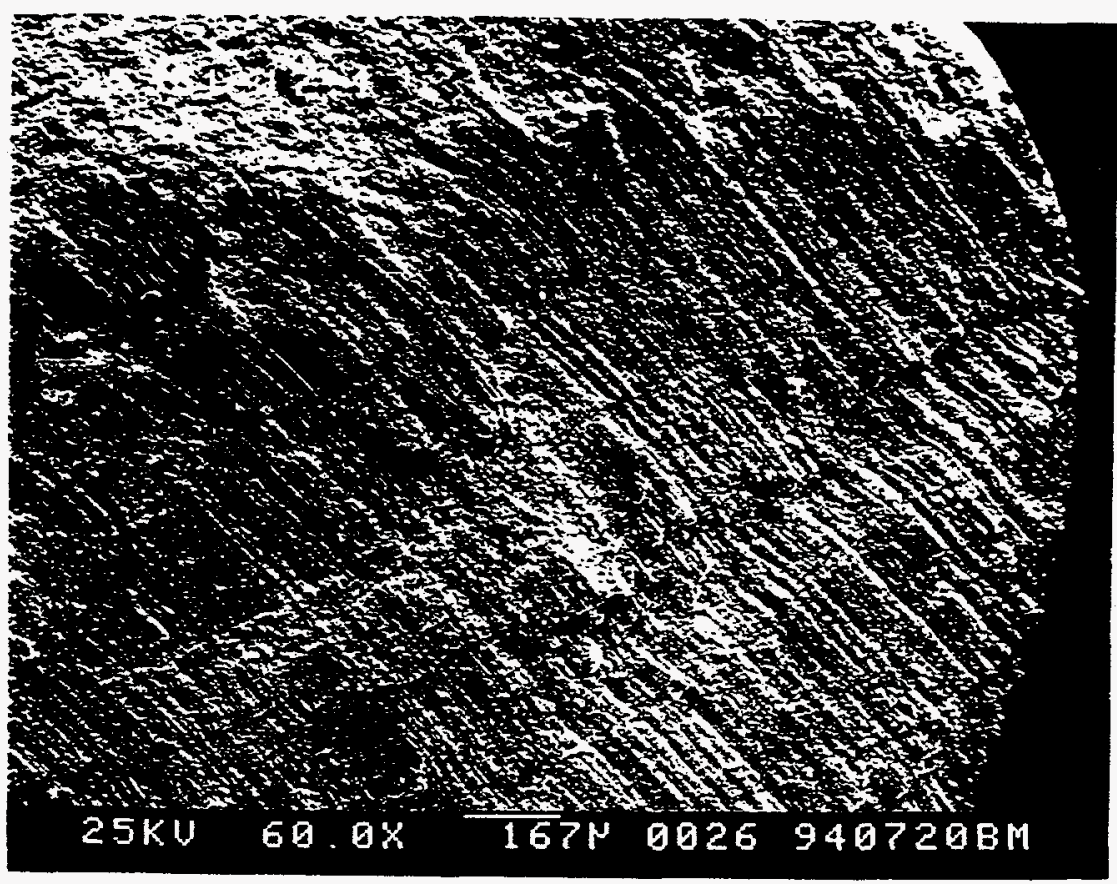

Figure 2 SEM of 25351-17-1 


\section{$25351-17-4$}

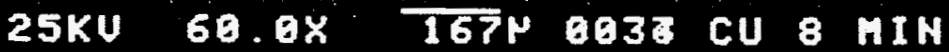

Figure 3 EDX Dot Map of 25351-17-4

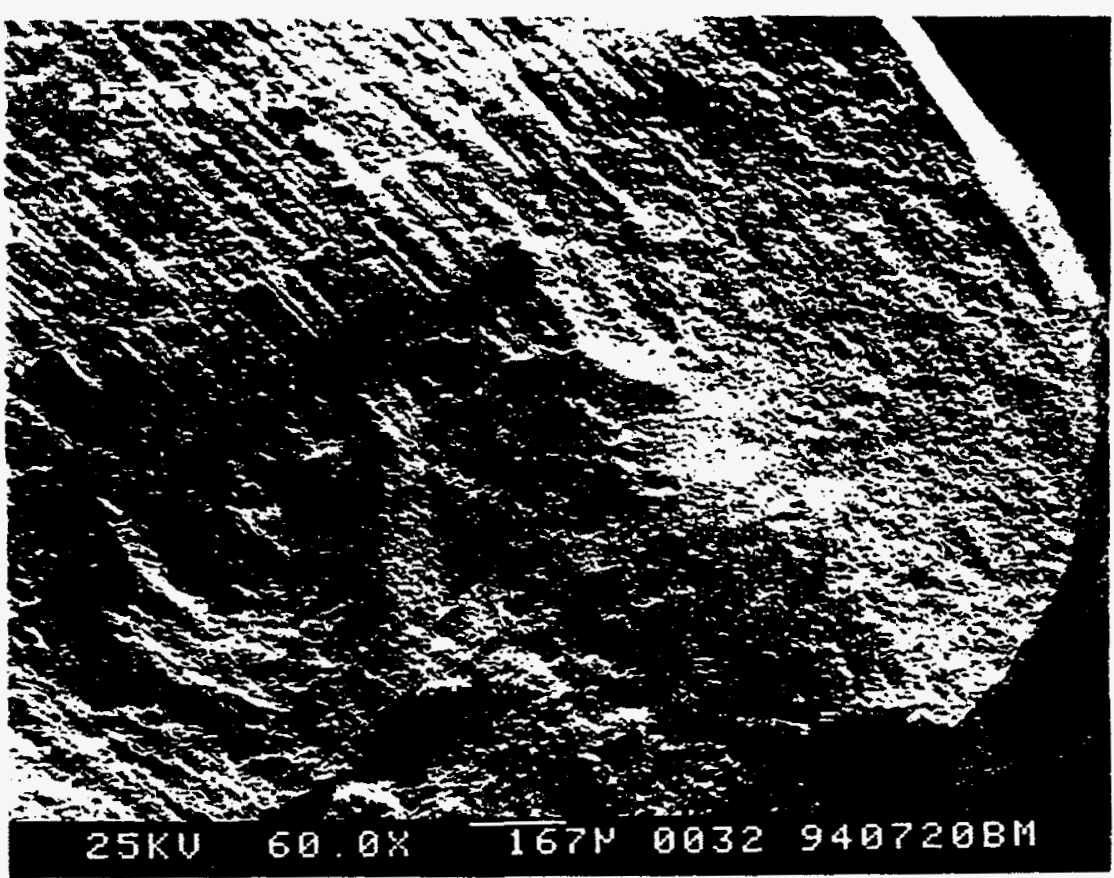

Figure 4 SEM of 25351-17-4 


\section{$25351-17-5$}

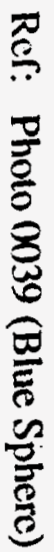

25KV 60.0X T67\% 0040 CU $4 \mathrm{MIN}$

Figure 5 EDX Dot Map of Blue Part of 25351-17-5

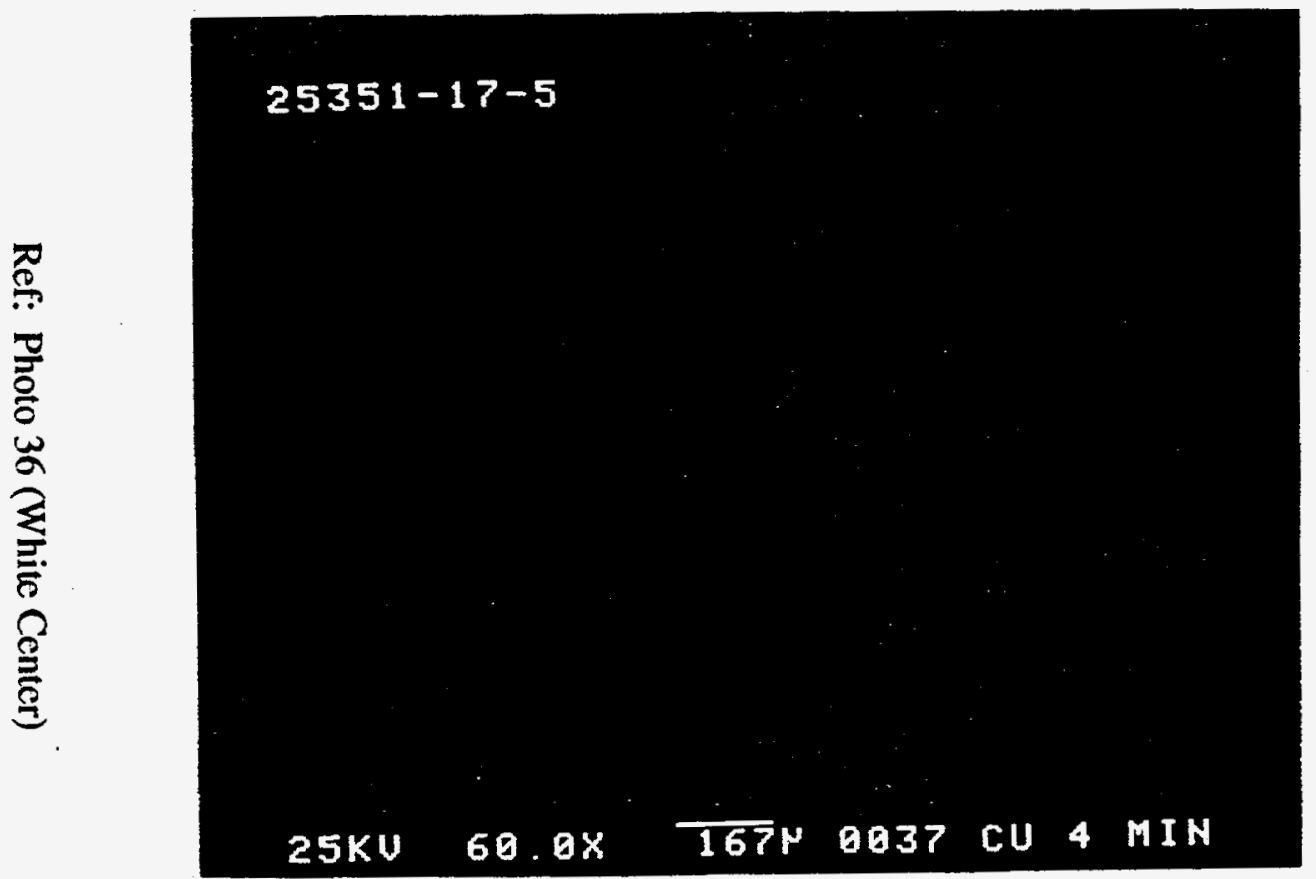

Figure 6 EDX Map of 25351-17-5 Including White Area (Left Center) 
$25351-17-6$

$25 \mathrm{KU} 60.0 \times$ T67N $0013 \mathrm{CU} 4 \mathrm{MIN}$

Figure 7 EDX Map of 25351-17-6

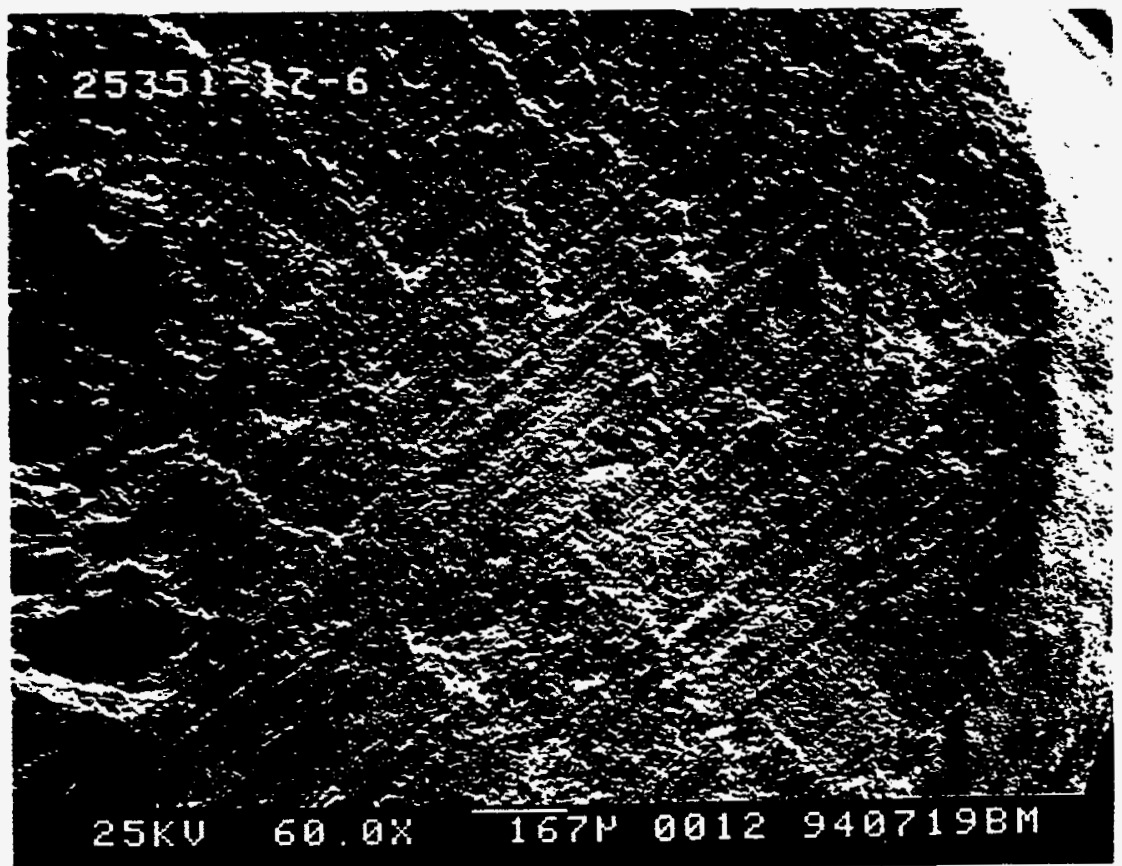

Figure 8 SEM of 25351-17-6 


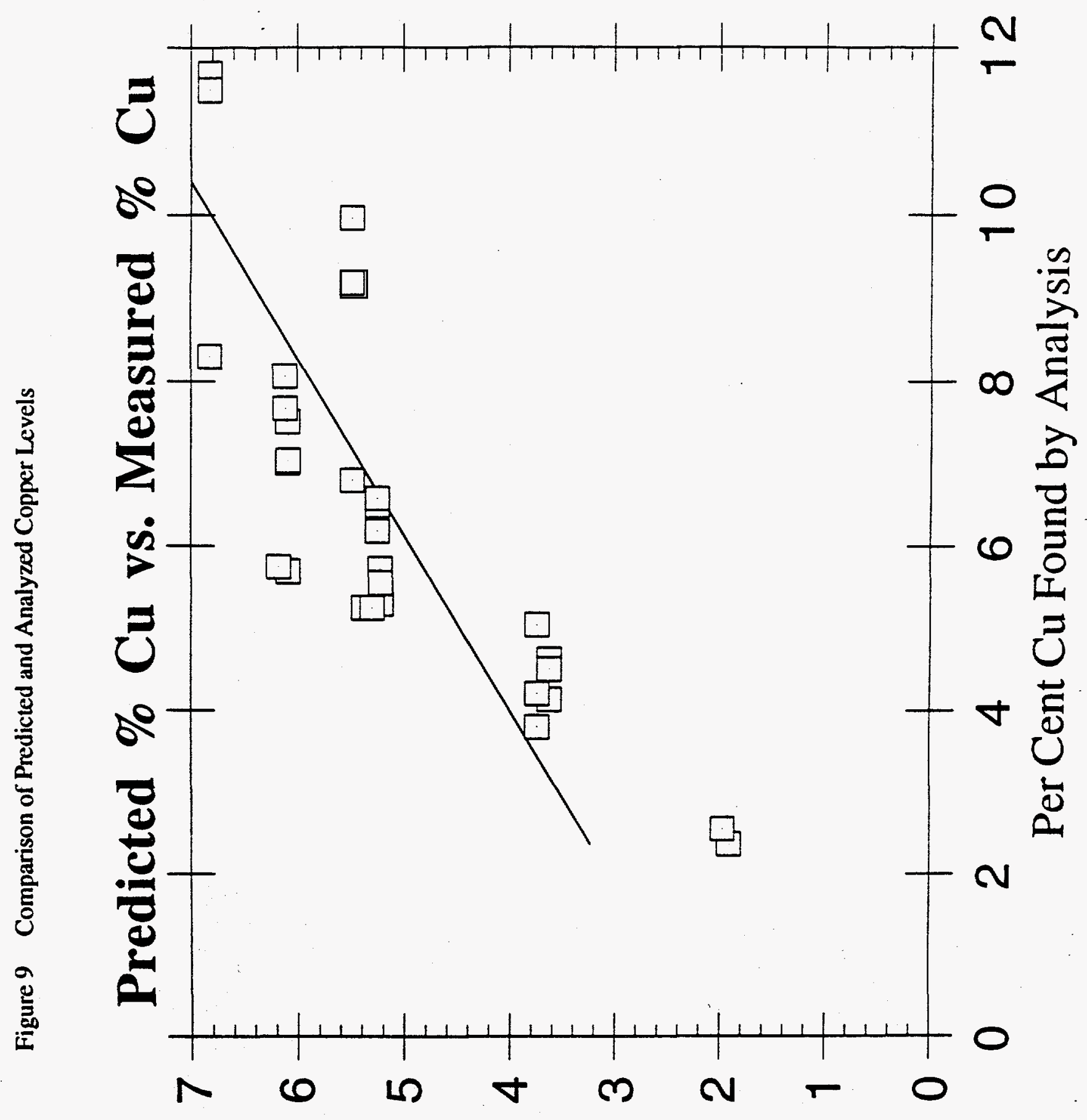

nว \% pəIе[กวएว 